\title{
Anti-NMDAR encefalitis als
} oorzaak van epilepsie bij een zesjarige jongen

Nieuw ontstane epilepsie bij kinderen en volwassenen kan wijzen op een auto-immuun oorzaak, met name als de epilepsie voorkomt in combinatie met neuropsychiatrische klachten of therapieresistent blijkt. Het is belangrijk om auto-immuun epilepsie snel te herkennen omdat de klinische uitkomst verbetert naarmate er sneller gestart wordt met behandeling. Vanwege de variatie in mogelijke klachten is het stellen van de diagnose vaak een uitdaging.

\section{Casus}

Een zesjarige gezonde jongen had tweemaal kort na elkaar een focaal insult met secundaire generalisatie, gevolgd door een post-ictaal beeld. Er was geen familiaire belasting voor epilepsie. Lichamelijk en neurologisch onderzoek waren ongestoord en hij had geen koorts. Tijdens een kortdurende opname traden geen nieuwe insulten op. Een dag later had de jongen opnieuw een aanval, waarbij hij ongedurig was, gevolgd door speekselvloed en een afwezige blik gedurende 20 minuten. Hierbij traden geen trekkingen op. In verband met verdenking op epilepsie werd gestart met carbamazepine. De MRI-hersenen toonde geen afwijkingen. Het EEG liet een functiestoornis links temporaal zien. Na een kortdurende opname werd hij ontslagen uit het ziekenhuis.

Na ruim twee weken werd de jongen opnieuw opgenomen omdat hij sinds twee dagen alleen losse woorden sprak en voorwerpen niet goed kon benoemen. Ook ging het spelen met lego minder goed en sliep hij slecht. Sinds de eerdere opname was hij boos en huilerig. Aanvankelijk werd dit geweten aan de eerdere insulten, maar ondanks uitblijven van nieuwe insulten persisteerden de gedragsveranderingen. Bij neurologisch onderzoek was de jongen prikkelbaar, mild apraktisch en had hij een motore afasie, waarbij hij enkel losse woorden sprak. Het EEG toonde een toename van de functiestoornis links temporopariëtaal. Vanwege de nieuw ontstane gedragsverandering werd carbamazepine gestaakt, en werd er gestart met valproïnezuur en clobazam voor de nacht. Desondanks ontwikkelde hij steeds meer gedragsveranderingen en traden er opnieuw focale insulten met verminderde gewaarwording op. Hij werd behandeld met een oplaaddosis intraveneus fenytoïne en ophoging van valproïnezuur. Vanwege aanhoudende insulten werd gestart met levetiracetam. De onrust en spraak- en taalstoornissen namen toe, waarvoor hij werd verwezen naar een academisch ziekenhuis. Daar ontwikkelde hij stereotype bewegingen, orofaciale dyskinesieën, katatonie, hallucinaties en autonome stoornissen. De liquor toonde een mononucleaire pleiocytose $\left(34 \times 10^{6}\right.$ cellen per liter, normaal $\left\langle 5 \times 10^{6}\right)$, zonder aanwijzing voor een bacteriële of virale encefalitis.

Vanwege het ziekteverloop, in combinatie met de bevindingen bij het aanvullend onderzoek, werd bij hoge verdenking op Anti-N-methyl-D-aspartaat receptor (anti-NMDAR) encefalitis gestart met een vijfdaagse intraveneuze behandeling met methylprednisolon (ivMP) $20 \mathrm{mg} / \mathrm{kg} / \mathrm{dag}$ en immunoglobulinen (IVIg) 0,4 gram $/ \mathrm{kg} / \mathrm{dag}$, gevolgd door oraal prednison. De eerder aangevraagde anti-NMDAR antistoffen bleken sterk positief in zowel serum als liquor. Er waren geen aanwijzingen voor nieuwvormingen. Vanwege gebrek aan voldoende herstel twee weken na start van de ivMP/IVIg kuur, werd rituximab als tweedelijns immunotherapie toegevoegd. De gedragsveranderingen werden symptomatisch behandeld met lorazepam en haloperidol. Hierna namen de dyskinesieën toe, waarop haloperidol werd vervangen door quetiapine. Ongeveer drie weken na start van de immunotherapie begon de jongen op te knappen. Hij sprak korte zinnen en het taalbegrip verbeterde. De gedragsmedicatie en prednisontabletten werden afgebouwd. Na een opname van ruim twee maanden werd hij ontslagen uit het ziekenhuis en kreeg hij poliklinische revalidatie. 
In de weken na het ontslag herstelden de spraak en het taalbegrip en kon hij weer fietsen en rennen. Resterende klachten waren overmatige vermoeidheid, concentratiestoornissen en gedragsstoornissen (sneller overprikkeld, boos en impulsiever dan voorheen). In de hierop volgende jaren werd de medicatie volledig afgebouwd en werd de revalidatie beëindigd. Inmiddels is het vier jaar na aanvang van de ziekte en kan de jongen met extra begeleiding het reguliere basisschoolonderwijs volgen. De gedragsveranderingen zijn nog in geringe mate aanwezig, maar duidelijk verbeterd na afbouwen van de anti-epileptica. Hij heeft nooit meer epileptische insulten gehad.

\section{Achtergrond en beschouwing}

Anti-NMDAR encefalitis is een neurologische auto-immuunziekte waarbij er antistoffen worden gevormd tegen de NMDA-receptor. Dit leidt tot een verstoorde functie van de hersenen. Patiënten met een anti-NMDAR encefalitis presenteren zich vaak met snel progressieve psychiatrische klachten, geheugenstoornissen, epilepsie en taalproblemen (Dalmau et al., 2019). Dit wordt gevolgd door een verlaagd bewustzijn met katatone kenmerken, dyskinesieën (met name orofaciaal) en autonome dysfunctie (Dalmau et al., 2019). Bij kinderen beginnen de symptomen vaker met neurologische, niet-psychiatrische klachten zoals insulten, dystonie en verminderde spraak (Titulaer et al., 2013, Dalmau et al., 20I9). Symptomen bij anti-NMDAR encefalitis kunnen initieel fluctueren, met name bij kinderen. Ook bij deze casus was dit het geval en werd de patiënt meermaals beoordeeld alvorens de definitieve diagnose werd gesteld.

De ziekte kan op alle leeftijden voorkomen, maar komt met name bij jonge vrouwen en kinderen voor (Florance et al., 2009, Titulaer et al., 2013, Dalmau et al., 2019). Ongeveer $35 \%$ van de patiënten is kind, terwijl vrouwen in de vruchtbare leeftijd zes keer vaker zijn aangedaan dan mannen van dezelfde leeftijd (Titulaer et al., 2013). Bij kinderen jonger dan $\mathrm{I} 2$ jaar en volwassenen ouder dan 45 jaar is de man-vrouw verhouding twee staat tot drie (Titulaer et al., 20I3). Eén derde van de patiënten met een anti-NMDAR encefalitis heeft een onderliggende tumor. Jonge vrouwen (in de leeftijd van 12 tot 35 jaar) hebben het hoogste risico op een tumor, $50 \%$ van hen heeft een ovariumteratoom (Titulaer et al., 2013). Dit in tegenstelling tot jonge kinderen, die vrijwel nooit tumoren hebben (Titulaer et al., 2013, Dalmau et al., 2019). Bij ouderen wordt in een kwart van de gevallen een tumor gevonden, vaak betreft dit een carcinoom en geen ovariumteratoom (Titulaer et al., 2013). Daarnaast is het aangetoond dat patiënten drie tot twaalf weken na een herpes simplex encefalitis een sterk verhoogd risico hebben op het doormaken van een anti-NMDAR encefalitis (Armangue et al., 20I4).

\section{De diagnose}

De diagnose wordt gesteld aan de hand van de in het kader weergegeven diagnostische criteria (Graus et al., 20I6), waarbij klinische herkenning essentieel is gezien de kans op normale aanvullende onderzoeken. Bij een patiënt met auto-immuun encefalitis bestaat het aanvullend onderzoek uit liquoronderzoek, een MRI-hersenen en een EEG. De lumbaalpunctie laat in $75-80 \%$ van de patiënten een pleiocytose zien (Titulaer et al., 2013). Bepaling van NMDARantistoffen is zowel sensitiever als specifieker in liquor dan in serum (Graus et al., 20I6). De MRI is bij anti-NMDAR encefalitis vaak (65\%) normaal (Titulaer et al., 2013). Het EEG toont meestal een diffuus vertraagd achtergrondpatroon. Een kwart van de patiënten vertoont epileptische activiteit. Bij ernstig aangedane patiënten met anti-NMDAR encefalitis kan het extreme delta brush patroon op een EEG

\section{Criteria probable anti-NMDAR encefalitis}

De diagnose kan gesteld worden indien aan alle drie onderstaande criteria wordt voldaan:

I. Subacuut ontstaan ( $<$ drie maanden) van minstens vier symptomen uit onderstaande zes groepen:

- Abnormaal (psychiatrisch) gedrag en cognitieve dysfunctie

- Epileptische aanvallen

- Spraakproblemen (verminderd spreken, mutisme)

- Bewegingsstoornis, dyskinesie of rigiditeit/abnormale houding

- Verminderd bewustzijn

- Autonome dysfunctie of hypoventilatie

2. Minstens één van de volgende bevindingen:

- EEG: focaal of diffuus vertraagd, epileptische activiteit of extreme delta brush patroon.

- Liquor: pleiocytose of aanwezigheid van oligoclonale banden.

3. Exclusie van andere oorzaken.

De diagnose kan ook gesteld worden bij aanwezigheid van een systemisch teratoom plus drie symptomen uit groep I.

\section{Definitie anti-NMDAR encefalitis}

De diagnose kan gesteld worden indien aan één of meer van de groepen van symptomen wordt voldaan en IgG anti-GluNI-antibodies aanwezig zijn in liquor, en andere oorzaken geëxcludeerd zijn. 
gezien worden, wat niet beschreven is bij andere ziektes (Schmitt et al., 2012).

\section{De behandeling}

Het doel van behandeling is om de immuunreactie te onderdrukken. Bij een onderliggende tumor is tumorresectie belangrijk om de aanzet tot antistofproductie weg te nemen. Ook bij een goedaardige tumor, zoals een ovariumteratoom, verbetert resectie de uitkomst. Daarnaast wordt de immuunreactie tegengegaan met immuunsuppressieve behandeling. Eerstelijnsbehandeling bestaat uit ivMP, IVIg en/of plasmaferese. Indien er binnen twee weken na de start van de behandeling geen klinische verbetering optreedt, is tweedelijnsbehandeling met rituximab en/of cyclofosfamide geïndiceerd. Daarnaast worden patiënten symptomatisch behandeld met anti-epileptica of antipsychotica. Deze middelen zijn vaak niet of matig effectief. Sommige middelen, zoals haloperidol, zijn niet gewenst omdat ze (al bij lage doseringen) bijwerkingen kunnen geven zoals het maligne neuroleptica syndroom of extrapiramidale bijwerkingen, zoals ook in deze casus is gebeurd (Lejuste et al., 20I6).

Het functionele herstel van patiënten is vaak goed na adequate behandeling, zelfs na langdurige opname op de intensive care (Titulaer et al., 2013, Dalmau et al., 2019). Ervaring leert dat de herstelperiode lang kan duren (maanden tot jaren). Ondanks goed functioneel herstel ervaren veel patiënten (ook kinderen) beperkende klachten na de ziekte. Deze bestaan veelal uit vermoeidheid, (subtiele) gedragsveranderingen en geheugenproblemen (de Bruijn et al., 20I9).

\section{Een bredere kijk op auto-immuun encefalitis} In navolging van de ontdekking van NMDAR-antistoffen zijn er steeds meer antistoffen tegen extracellulaire (membraan)eiwitten geïdentificeerd. Voorbeelden hiervan zijn antistoffen tegen LGII, de $\mathrm{GABA}_{\mathrm{B}}$-receptor, Caspr2 en DPPX. Deze antistoffen leiden ieder tot auto-immuun encefalitis, maar de symptomen zijn afhankelijk van het type antistof.

Voorheen waren er enkel antistoffen tegen intracellulaire eiwitten bekend, paraneoplastische antistoffen genoemd. Deze antistoffen zijn sterk gerelateerd aan tumoren. Ze hebben geen direct pathogeen effect op het targeteiwit, maar worden beschouwd als een epifenomeen. Het directe pathogene effect wordt veroorzaakt door een cytotoxische T-cel reactie. Deze aandoeningen reageren daardoor zelden op immunotherapie. De neurologische klachten zijn progressief en stabilisatie is vaak het hoogst haalbare (Dalmau \& Rosenfeld, 2008).

In tegenstelling tot de intracellulaire eiwitten zijn de meer recent ontdekte antistoffen tegen extracellulaire eiwitten (zoals anti-NMDAR) minder vaak geassocieerd met tumo- ren. Ze hebben een pathogeen effect via interactie met targeteiwitten en patiënten reageren daardoor meestal goed op immunotherapie, hoewel niet altijd direct. Dit biedt behandelopties; door vroeg in het ziekteverloop te behandelen wordt een betere uitkomst bereikt en kan irreversibele schade worden voorkomen. Hoewel de incidentie van deze ziekten laag is, is snelle herkenning zeer belangrijk omdat immunotherapie (ook bij ernstig zieke patiënten) meestal leidt tot een goede behandeluitkomst. Herkenning van het ziektebeeld is echter niet altijd gemakkelijk, doordat de symptomen divers zijn, op alle leeftijden kunnen voorkomen en de incidentie laag is. Door de diversiteit in presenterende symptomen kunnen allerlei soorten artsen geconsulteerd worden in de eerste fase van de ziekte. Dit maakt snelle herkenning niet alleen door de (kinder)neuroloog, maar ook voor andere zorgverleners van belang. Het is met name belangrijk alert te zijn op auto-immuun encefalitis bij patiënten met een combinatie van subacuut ontstane, progressieve neuropsychiatrische symptomen, waaronder cognitieve klachten, epileptische aanvallen, bewegingsstoornissen en een psychose. Ook onverklaarde refractaire epilepsie en het krijgen van bijwerkingen bij relatief lage doseringen antipsychotica en anti-epileptica zijn rode vlaggen.

\section{Epilepsie en auto-immuun encefalitis}

Epilepsie komt voor bij 50-95\% van de patiënten met autoimmuun encefalitis (Irani et al., 20II). Epilepsie komt het meest voor bij antistoffen tegen NMDAR, AMPAR, LGII, Caspr2, GAD65 (bij hoge antistof titer), $\mathrm{GABA}_{\mathrm{A}} \mathrm{R}$ en $\mathrm{GABA}_{\mathrm{B}} \mathrm{R}$. Bij kinderen worden met name antistoffen tegen de NMDAR gezien, de overige antistoffen zijn zeldzaam. Insulten kunnen het presenterende symptoom zijn, maar kunnen ook voorkomen nadat een patiënt al gedrags- of cognitieve stoornissen heeft ontwikkeld. In ongeveer $4 \%$ van de patiënten met onverklaarde focale epilepsie blijkt de epilepsie veroorzaakt door een autoimmuun encefalitis (de Bruijn et al., 20I9). Bij patiënten met nieuwe onverklaarde status epilepticus is dit 30-40\% (ongepubliceerde informatie). Patiënten met epilepsie ten gevolge van auto-immuun encefalitis vrijwel altijd aanvalsvrij na immunotherapie, waarbij ook de anti-epileptica kunnen worden gestaakt (de Bruijn et al., 20I9).

\section{Conclusie}

Bij kinderen met een nieuw ontstane epilepsie zonder duidelijke etiologie is het belangrijk om auto-immuun encefalitis als diagnose te overwegen. Klinische aanknopingspunten kunnen zijn; neuropsychiatrische symptomen, bewegingsstoornissen, autonome stoornissen en overgevoeligheid voor anti-psychotica en anti-epileptica. Snelle herkenning en behandeling van deze ziektebeelden dragen bij aan een betere behandeluitkomst. 


\section{Referenties}

Armangue T et al. (20I4) Herpes simplex virus encephalitis is a trigger of brain autoimmunity. Ann Neurol, 75, 317-23.

Dalmau J et al. (2019) An update on anti-NMDA receptor encephalitis for neurologists and psychiatrists: mechanisms and models. Lancet Neurol.

Dalmau J et al. (2008) Paraneoplastic syndromes of the CNS. Lancet Neurol, 7, 327-40.

De Bruijn MAAM et al. (2019) Evaluation of seizure treatment in anti-LGI, anti-NMDAR, and anti-GABABR encephalitis. Neurology, 92, e2185-e2I96.

De Bruijn MAAM et al. (20I9) Antibodies Causing focal Epilepsy Signs and symptoms (ACES) score. A prospective, multicenter, observational cohort study. Abstract American Academy of Neurology.

Florance NR et al. (2009) Anti-N-methyl-D-aspartate receptor (NMDAR) encephalitis in children and adolescents. Ann Neurol, 66, II-8.
Graus F et al. (20I6) A clinical approach to diagnosis of autoimmune encephalitis. Lancet Neurol, I5, 39I-404.

Irani SR et al. (20II) Autoimmune epilepsies. Curr Opin

Neurol, 24, I46-53.

Lejuste F et al. (20I6) Neuroleptic intolerance in patients with anti-NMDAR encephalitis. Neurol Neuroimmunol Neuroinflamm, 3, e280.

Schmitt SE et al. (20I2) Extreme delta brush: a unique EEG pattern in adults with anti-NMDA receptor encephalitis. Neurology, 79, I094-Ioo.

Titulaer MJ et al. (2013) Treatment and prognostic factors for long-term outcome in patients with anti-NMDA receptor encephalitis: an observational cohort study. Lancet Neurol, I2, I57-65.

\section{Genetische diagnostiek bij epilepsie}

De kennis over genetische oorzaken van epilepsie, de mogelijkheden van genetische diagnostiek en de implicaties van een genetische diagnose nemen steeds meer toe. Deze bijdrage geeft een overzicht van de huidige stand van zaken.

Genetische testen bij epilepsie

Dankzij de implementatie van moderne technieken van DNA-onderzoek is de opbrengst van genetische diagnostiek bij patiënten met epilepsie de afgelopen vijftien jaar sterk toegenomen. De huidige diagnostiek kan de volgende testen omvatten:

- Een array analyse, waarmee wordt onderzocht of er kleine delen van een chromosoom ontbreken (deleties) of verdubbeld aanwezig zijn (duplicaties).

- Epilepsie genpanelonderzoek: onderzoek van een panel van genen voor (een bepaald type) epilepsie. Op dit moment is van enkele honderden genen bekend dat zij een rol kunnen spelen bij epilepsie.

- Exoomsequencing: onderzoek van alle ruim 20.000 genen van een persoon.

- Karyotypering: onderzoek naar het aantal en de structuur van de chromosomen.

- Onderzoek van één of enkele individuele genen.

De eerste vier onderzoeken hebben een screenend karakter en vereisen geen hypothese vooraf over de precieze genetische afwijking. Gericht onderzoek van één gen wordt alleen gedaan als er een sterk vermoeden is dat een afwijking in het betreffende gen een rol speelt.

\section{Mogelijke bevindingen}

Bij een recente meta-analyse van 20 studies naar de opbrengst van genetische diagnostiek bij patiënten met epilepsie werd met array analyse bij $8 \%$ van de patiënten een diagnose gesteld, met epilepsie genpanelonderzoek bij $23 \%$ en met exoomsequencing bij $45 \%$ (Sánchez Fernandez, et al., 2019). Deze getallen hebben betrekking op vaak wisselend geselecteerde patiënten met een indicatie voor genetische diagnostiek.

Doel van genetische diagnostiek is het aantonen van een DNA-variant die een oorzaak is van de epilepsie. Deze DNA-varianten kunnen van (één van beide) ouders zijn geërfd of bij de persoon met epilepsie nieuw (de novo) zijn ontstaan. Er kunnen echter ook andere uitkomsten zijn. Zo kunnen er DNA-varianten worden aangetoond 